\title{
水理学的知見に基づく自由落下型落水形態の表情予測とデザイン方法論 \\ An Estimation of the Texture of Free Falling Water Based on Hydraulic Theories and its Application to a Water Design Method
}

\author{
星野 裕司* 篠原 修** \\ by Yuji HOSHINO, Osamu SHINOHARA
}

\section{1. 背景と目的}

堰や落差工等の河川横断構造物では、水の流れが 落水となって現れ、その表情は常に河川景観の重要 な魅力の一つとなっている。しかし、利水、治水の 要請から設置されている河川構造物の設計において は、残念ながらその落水表情の魅力が考慮されてい ることは稀である。一方落水表情が主題の一つとな る人工の滝においても、そのデザインは専らデザイ ナ一の経験に基づき、客観的な水理学的考察はなさ れていない。

ともするとデザインとは、デザイナーの主観的な 意図や恣意によると考えられているが、水の流れの ように自然と強く関わり、自然の表情がその魅力と なる構造物においては、自然の合理性に基づくデザ イン方法論が存在するはずである。

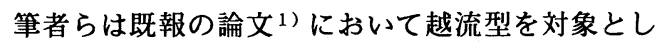
て落水表情を論じた。その成果を踏まえて本研究で は、自由落下型の落水形態を呈する構造物を対象と する。本論の目的は、まず現実に存在する堰、落差 工及び人工の滝等を対象として落水表情を分類し、 次に既存の水理学経験式等を適用することでその規 定要因を考察し、それに基づいて構造物の設計時に 落水表情の予測、制御が容易に可能となる表情予測 手法を中心とするデザイン方法論を提示することで ある。

以上のように本研究は、既存の水理学上の成果に 依存し、その限界を超えるものではなく、また水理 学上の新たな知見を得ようとしたものでもない。本 論の意義は景観的視点から落水現象を全体的に把握

キーワード：景観、空間設計、河川構造物

- 学生員 東京大学大学院工学系研究科土木工学専攻

* 正会員 工博 東京大学教授 工学部土木工学科

（テ113東京都文京区本郷7-3-1、TEL 03-3812-2111、

FAX 03-3818-5692)
し、そのメカニズムを簡便なモデルを用いて記述す ることで、理論を現実の設計において適用できるも のとしてまとめ直すことにあると考えている。

\section{2. 落水表情の分類}

\section{（1）落水表情の分類}

落水表情において、最も重要な役割を演じるものは 空気混入度、水の白み方である。つまり、その水脈の 乱れ方が落水表情に強く影響すると考えられる。

本論では自由落下型の落水表情を、落水発生部（落 水過程 I ) 、落水部 (落水過程 II) 、着水部（落水過 程 III）の 3 つ過程に分類した。視覚的な表情と水理 学的な意味の 2 つの視点から表情分類をそれぞれの過 程に対して行うと図 1 のようになる。実際の表情には

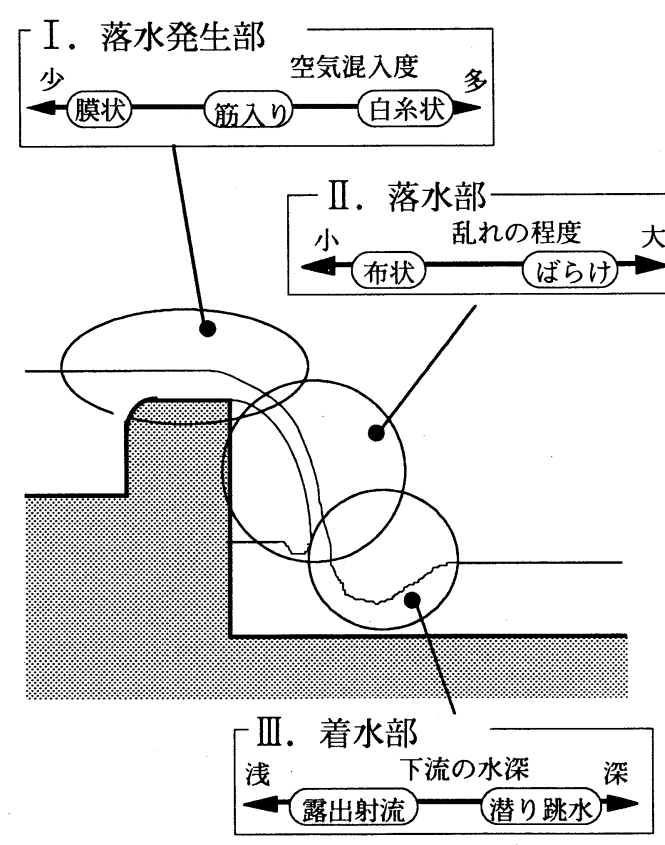

図 1 表情分類図 
光の当たり具合の影響も大きいが、本論では水理学的 に考察できるもののみに限っている。

（2）表情の定義

（a）落水発生部（落水過程 I ）

自由落下型落水は通常の開水路流れとは異なっ て、水脈の表側と裹側に 2 面の白由表面を持ち、そ れぞれの自由表面は簧なった流沇を示す場合があ る。そのため本論では落水発生部の表情を以下の 3 つに分類し、定義した。

·莫状（写真 1) : 水脈の表面、噈面共に滑らかで あり、空気混入は起こらず透明な膜として落ちて いる状態。

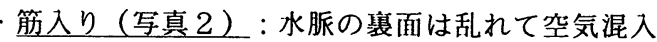
が起こっているが、表面は滑らかなままの状態。 この表情は他の 2 つに比べて幅が広く、裹面に入 る白みには線状のものからより白みの大きい泡状 のものまでと多様である。

白糸状 (写真 3 ) : 水脈の表面、裏面共に乱れて いて、空気混入が大きく水脈全体が白んで白糸状 に落ちている状態。

（b）落水部（落水過程 II）

ここでは落水脈の安定、不安定によって、その表 情を以下の $2 つ に$ 分類、定義した。

·丕安定（ばらけ）（写真 1 、写真 3 ）：落水中に 水脈が不安定になり、途中からばらばらっと水粒 が全方向的にばらけて落ちている状態。

安定（布状）（写真2）：上記のようなばらけが 発生せず、そのまま 1 枚の布のように落ちている 状態。

（c）着水部（落水過程 III）

ここでは着水後の跳水の形によって、以下の $2 つ$ に定義した。

- 露出射流（写真 $2 、$ 写真 3 ）：着水時に跳ね上が るように泡が出ている状態。

- 潜り跳水（写真 1) : 水脈が下流の水面に潜った ようにごぼごぼと泡が出ている状態。

ここに分類した表情は、それぞれの過程において 独立である（例えば、過程 I の 3 つの表情は過程 II においてそれぞれ、ばらけか布状どちらにも移るこ とが出来る）。つまり自由落下型の落水は全体とし て、3つの過程それぞれに分類した表情の組み合わ せ、計 12 種類の表情に分かれる。

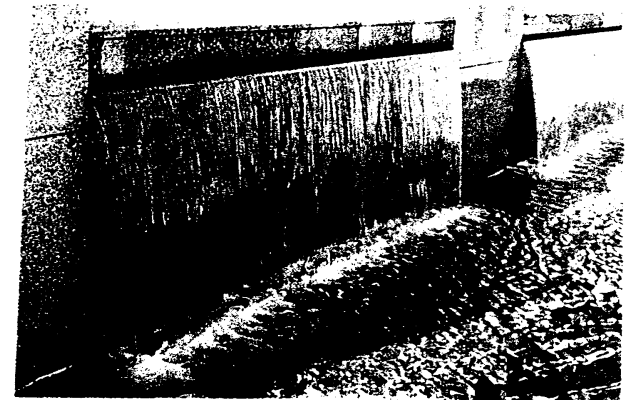

写真 1 膜状ーばらけ一潜り跳水

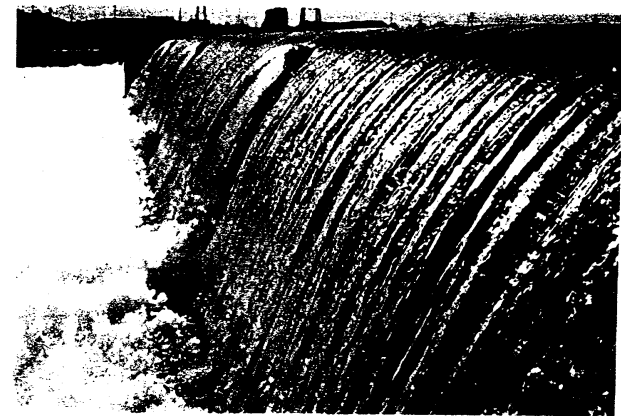

写真 2 筋入り一布状一露出射流

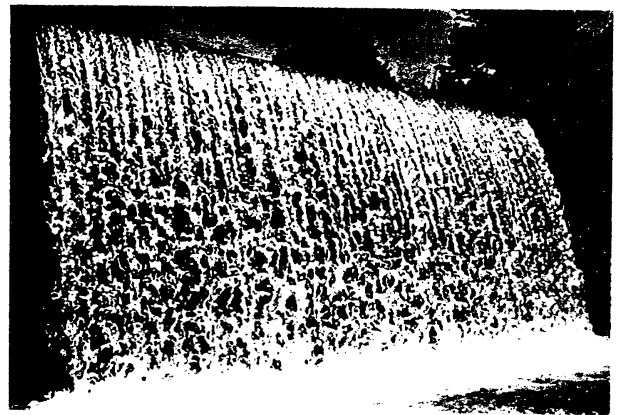

写真 3 白糸状一ばらけ一露出射流

3. 水理学的考察と表情予測モデル

\section{（1）規定要因の整理}

前章で分類した表情を規定する水理学的要因を整 理すると図 2 のようになる。ここで、1 次要因とは 本論で考察する要因であり、落水形態や表情の基本 を与えるものである。また 2 次要因は現実の表情に 対して影響が大きいと考えられるが、既存の水理学 上の知見では考察が困難かつ複雑であり、本論の性 格上今回は考慮していない。それらに対する考察 は、今後の課題である。 


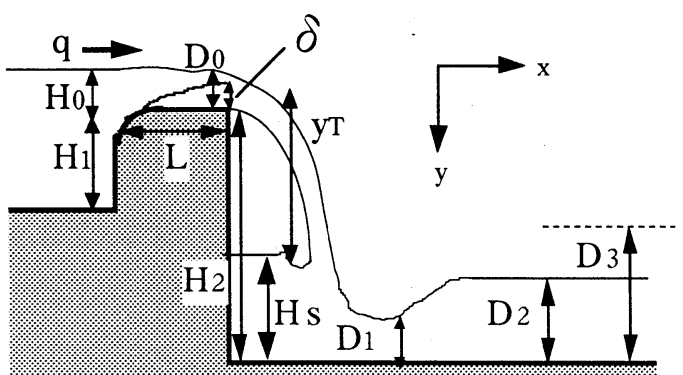

\begin{tabular}{|c|c|c|c|c|c|}
\hline 落水過程 & \multicolumn{4}{|c|}{1 次要因 } & 2 次要因 \\
\hline$I$ & $\begin{array}{lr}\begin{array}{l}\text { 天端長さ } \\
\text { 限界水深 }\end{array} & \text { D } 0 \\
\text { 境界層厚さ } & \delta\end{array}$ & & \multirow{2}{*}{\multicolumn{2}{|c|}{$\begin{array}{ll}\text { 単位幅流量 } & \mathrm{q} \\
\text { 坺上げ高さ } & \text { H } 1 \\
\text { 越流水深 } & \text { H } 0\end{array}$}} & $\begin{array}{l}\text { 天端の粗度 } \\
\text { 落ち口の形状 } \\
\text { 上流条件 } \\
\text { (流速、河床) } \\
\text { 水脈表側の気圧 }\end{array}$ \\
\hline$\prod$ & $\begin{array}{llll}\text { 落差高さ } & \text { H } 2 & \\
\text { 落下高さ } & \text { y } & & \\
\text { 着水上流水深 } & \text { Hs }\end{array}$ & & & & 風 \\
\hline III & $\begin{array}{l}\text { 下流設定水深 } \\
\text { 水路床での射流水深 } \\
\text { D1に対する共役水深 }\end{array}$ & $\begin{array}{ll}\text { D } & 3 \\
\text { D } & 1 \\
\text { D } & 2\end{array}$ & & & 下流儧の河床条件 \\
\hline
\end{tabular}

図2 規定要因

（2）落水過程 I（落水発生部）について

ここで考察したいのは水脈の乱流状態である。落 水発生部の表情において重要な要因となるのは空気 混入の程度である。一般に水脈への空気混入に対す る条件として、乱流境界層が自由表面に達した点か ら空気混入が開始されると言う必要条件しか設定さ れておらず、必要十分条件ではないが、本論はこの 知見に従うものである。よってこの過程の水理学的 考察では、その境界層問題を解くことにより水脈の 乱流状態を把握し、境界層の厚さを導き出したい。 操作可能なデザインパラメーターは、流水に関して 単位幅流量 $(q)$ 、構造物に関して堰上げ高さ （H1）と天端の長さ（L) である。

i ）標準越流頂における越流水頭（H）は、岩崎 公式2)によると次のように求まる。

$$
\begin{aligned}
& \mathrm{q}=\mathrm{CH}^{\frac{3}{2}} \cdots \text { (1) } \\
& \mathrm{C}=2.200-0.0416\left(\frac{\mathrm{H}}{\mathrm{H}_{1}}\right)^{0.99} \cdots(2)
\end{aligned}
$$

$\mathrm{C}:$ 流量係数、 $\mathrm{H}$ : 越流水頭 $(\mathrm{m})$

この時、接近流速を $\mathrm{O}$ と伋定すると $\mathrm{H}=\mathrm{H}$ 它なる。

また、広頂堰において天端上流端が角張っている ときはそこで剥離が起こりその最高位置で支配断面 となるが、Ippen ${ }^{3)}$ は、天端上流端に丸みがついて
いる場合天端下流端が支配断面となり、その断面に ついて限界水深となると仮定している。よってその 時の水深（D0）は、

$$
\mathrm{D}_{0}=\frac{2}{3} \mathrm{H} \cdots \text { (3) }
$$

となる。

ii）物体表面上に発達する境界層のReynolds 数は 以下によって求まる。

$$
\begin{aligned}
& \mathrm{Rx}=\frac{\mathrm{vx}}{v} \cdots \text { (4) } \\
& \nu: \text { 動粘性係数 } \quad\left(1.0 \times 10^{-6} \mathrm{~m}^{2} / \mathrm{s}\right) \\
& \text { この時、 } \\
& \mathrm{x}=\mathrm{L} \cdots \text { (5) } \\
& \mathrm{v}=\sqrt{\frac{2 \mathrm{gH}_{0}}{3} \cdots \text { (6) }}
\end{aligned}
$$

(5)、(6)を (4)式に代入すると、天端下流端の Reynolds数が求まる。乱流と層流に分ける遷移 Reynlds 数は、

$$
\text { 遷移Reynolds 数 }=3 \times 10^{5} \cdots \text { (7) }
$$

で与えられ、境界層が乱流となるとき、水脈の裹 面から空気混入が生じると考えられる。これによっ て、膜状と筋入りの境界が与えられる。

iii）Ippen によると、乱流境界層の発達は以下に よって与えられる。

$$
\begin{aligned}
& \frac{\delta_{\star}}{x}=0.63 \mathrm{Cf} \cdots(8) \\
& \frac{1}{\sqrt{\mathrm{Cf}}}=1.70+4.15 \log _{10}(\mathrm{RxCf}) \cdots(9)
\end{aligned}
$$

$\delta_{*}$ : 排除厚さ（これは10式によって定義され、外 流の流線を壁から $\delta_{*}$ だけ押し上げるのと同じ効果が ある。)

$$
v \delta_{*}=\int_{0}^{\delta}(v-u) d y \cdots(10)
$$

また、乱流境界層内の速度分布は次によって与え られる4)。

$$
u=v\left(\frac{y}{\delta}\right)^{\frac{1}{7}} \ldots \text { (11) }
$$




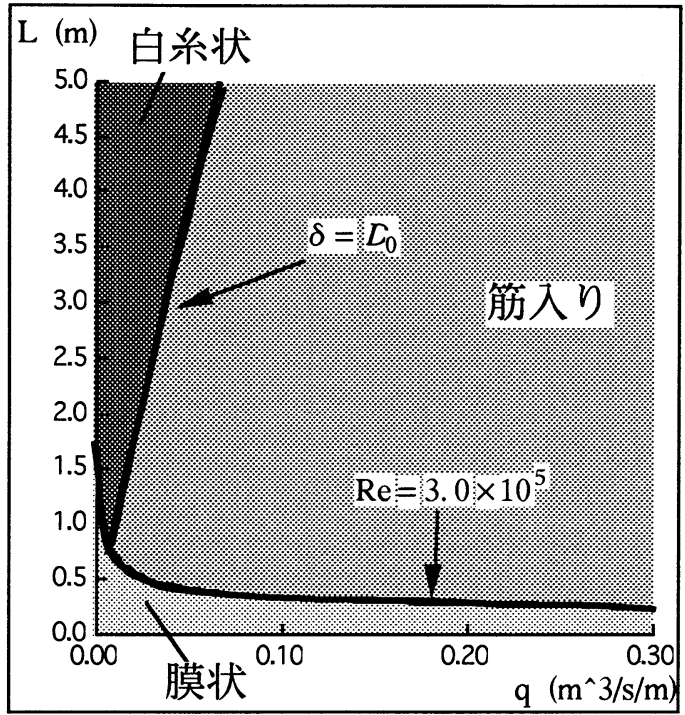

図 3 表情予測図 (I)

(11)、(10)

$\delta=8 \delta_{*} \cdots$ (12)

8)、(9)、12式を解くことで乱流境界層厚さ（ $\delta$ ) が求まる。この $\delta$ が水脈表面まで達すると表面、裏 面共に乱れるため白糸状になる必要条件を満たし、 達していなければ筋入りとなる。

以上によって得られた諸条件を落水表情予測図と して図 3 に示す。

（3）落水過程 II（落水部）について

ここでは、落水脈がばらける不安定条件を求めた い。この現象に対して、既存の適切な公式が見あた らないため、今回は落下する水束の不安定条件を採 用した。この不安定条件は水と空気の界面での表面 張力と流速の関係で決定される。但しこのモデルで は、等速落下及び非粘性ポテンシャル流という仮定 がなされており、本論で扱う落水とは条件が異なる が、この問題については検証で取り上げ論ずる。デ ザインパラメーターは、流水に関しては過程 I と同 梯に単位幅流量 $(\mathrm{q})$ 、構造物に関しては落差高さ （H2）である。

i ）落下水脈の中心線の軌跡曲線は次によって与 えられる5)。

$$
\frac{x}{H}=1.477\left(\frac{y}{H}+0.242\right)^{0.567} \cdots(1)
$$

水脈の水面への突入角度を $\theta$ とすると、(1)式から $\operatorname{Tan}\left(90^{\circ}-\theta\right)=1.477 \times 0.567 \times\left(\frac{y}{H}+0.242\right)^{-0.433}$ $\cdots(2)$

となる。水脈の着水点より上流に形成される水深 （Hs）は以下によって求まる。WHITE式 6)より、

$$
v_{T}=\sqrt{2 g\left(H+y_{T^{-}} \frac{D_{0}}{2}\right)} \cdots \text { (3) }
$$

$\mathrm{V}_{\mathrm{T}}$ : 落下水脈の水面への突入流速 $(\mathrm{m} / \mathrm{s})$

$$
\begin{aligned}
& y_{T}=H_{2}+\frac{D_{0}}{2}-H s \cdots(4) \\
& H s=\sqrt{\frac{2 V_{T} q(1-\cos \theta)}{g}+\frac{4 q^{2}}{V_{T}{ }^{2}(1+\cos \theta)^{2}}} \cdots \text { (5) }
\end{aligned}
$$

(2)、(3)、(4)、(5)式によって、 $\theta 、 \mathrm{VT} 、 \mathrm{yT} 、 \mathrm{Hs}$ が求 まる。

ii）落下水束の不安定条件は、Chen、Davis ${ }^{7)}$ に よって以下によって与えられる。

$\frac{h}{a^{\prime}}=1.15 \mathrm{We}+30 \cdots$ (6)

$W e=\sqrt{\frac{\varrho_{a} v^{2} a^{\prime}}{T} \cdots(7)}$

h : ばらけまでの距離 $(\mathrm{m}) 、 \mathrm{a}^{\prime}$ : 内径 $(\mathrm{m})$ 、

$\rho \mathrm{a}:$ 空気の密度 $\left(1.2 \mathrm{~kg} / \mathrm{m}^{3}\right) 、 \mathrm{v}:$ : 流速 $(\mathrm{m} /$

s) 、 $\mathrm{T}$ : 表面張力 $(0.74 \mathrm{~kg} / \mathrm{cm})$

$$
\begin{aligned}
& \text { ここで } \quad a^{\prime}=D_{0} \cdots(8) \\
& v=\sqrt{2 g\left(H+y-\frac{D_{0}}{2}\right)} \cdots(9)
\end{aligned}
$$

とすると、h がもとまる。

iii）上記のように求まつた落下距離（ $\mathrm{yT}$ ) とばら けまでの距離（h）の比較によって布状かばらけかの 評価を行う。つまり、 $\mathrm{yT}<\mathrm{h}$ ならば落水中にばらけ は生じず布状である。逆に $\mathrm{yT}>\mathrm{h}$ ならばばらけとな る。この落水表情予測図を図 4 に示す。 


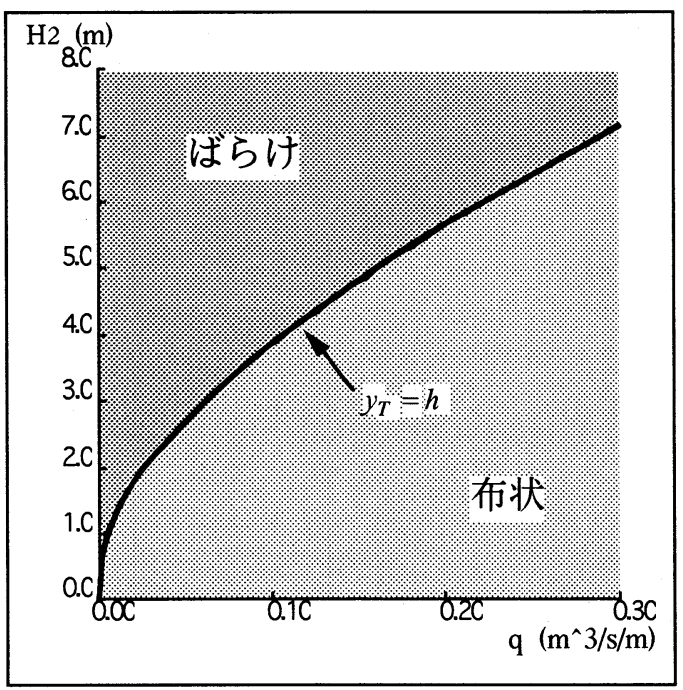

図4 表情予測図（II）

（4）落水過程 III（着水部）について デザインパラメーターは、流水に関しては単位幅 流量（q）と下流設定水深（D3）であり、構造物に 関しては落差高さ（H2）である。ここでは、跳水の 形について水理学的考察を行うが、それは着水時の 水路床での射流水深（D1）とその共役水樑（D2）、 下流設定水深（D3）の関係によって決定される。

i ）（3）の i ）で求められた突入角度 $(\theta)$ 、 突入流速 $(\mathrm{VT})$ と流量一定の法則より

$D_{\mathrm{T}}=\frac{\mathrm{q}}{\mathrm{V}_{\mathrm{T}}} \cdots(1)$

DT : 落下水脈の突入水深 $(\mathrm{m})$

WHITE式より $\mathrm{V}_{1}=\frac{\mathrm{V}_{\mathrm{T}}(1+\cos \theta)}{2} \cdots$ (2)

$\mathrm{V}_{1}$ : 水路床での射流流速 $(\mathrm{m} / \mathrm{s})$

$\mathrm{D}_{1}=\frac{\mathrm{q}}{\mathrm{V}_{1}} \cdots$ (3)

水脈のFruode 数は

$\mathrm{Fr}=\frac{\mathrm{V}_{1}}{\sqrt{\mathrm{gD}_{1}}} \cdots(4)$

よってD1に対する共役水深（D2）は、

$\mathrm{D}_{2}=\frac{1}{2} \mathrm{D}_{1}\left(\sqrt{1+8 \mathrm{Fr}^{2}}-1\right) \cdots$ (5) となる。

ii）安芸8)によると下流設定水深（D3）とD2の比

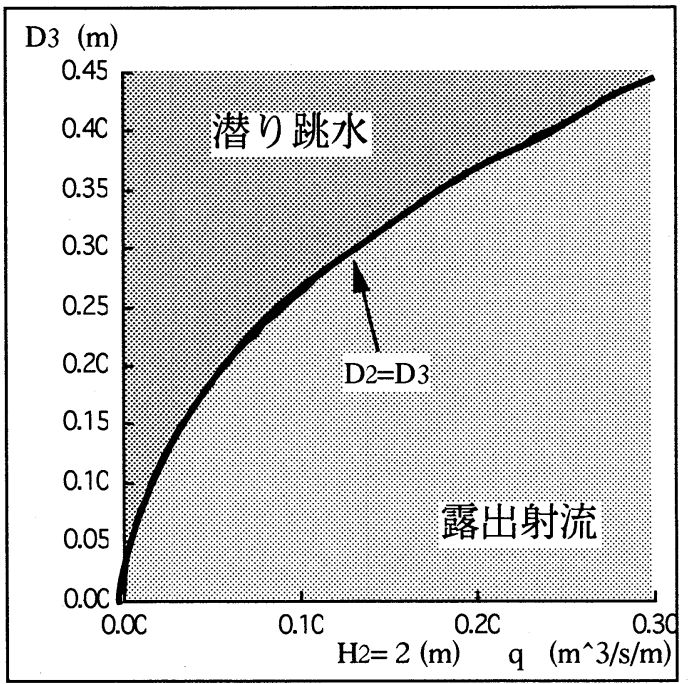

図 5 表情予測図 (III)

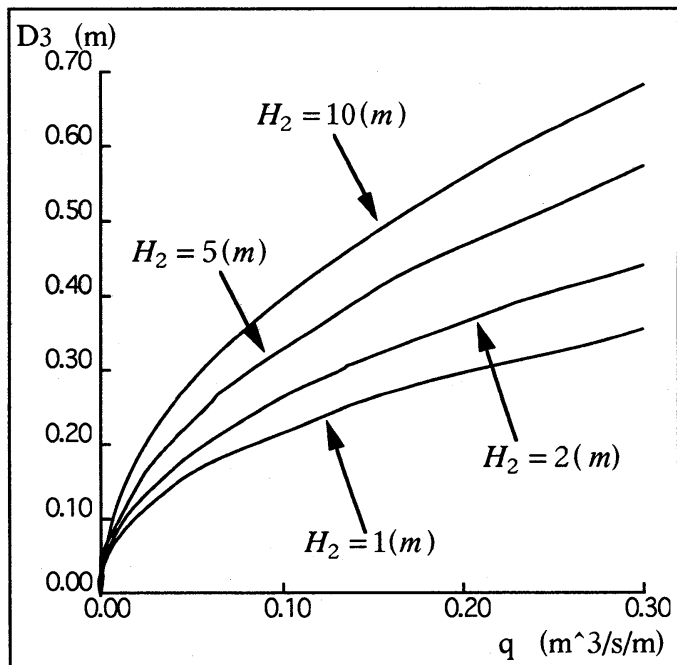

図 6 落差高さによる境界变化

較によつて跳水の形態は決定される。つまり $\mathrm{D}_{2} \geqq \mathrm{D} 3$ ならば露出射流、 $\mathrm{D} 2<\mathrm{D} 3$ ならば潜り跳水となる。落 水表情予測図を図 5、6に示す。

\section{3. 予測モデルの検証}

\section{（1）検証の目的と方法}

前章において、落水表情の予測モデルを提示し、 予測図を作成したが、様々な水理学経験式の複合体 であるそれらがそのまま現実の表情に対応できると は考えにくい。また本論は、現実のデザインへの応 用を目的としている以上、モデルと現実の表情との 


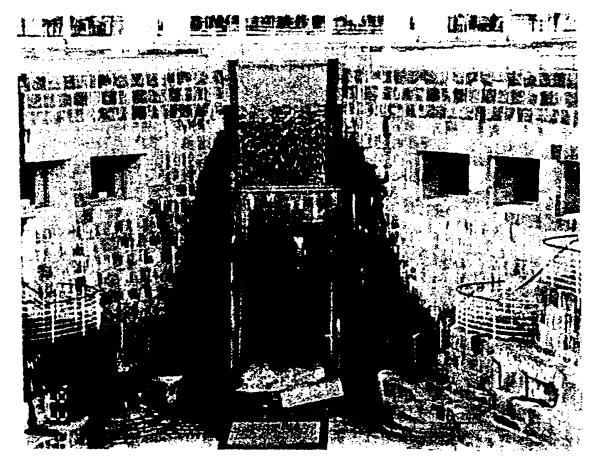

写真4 横浜ドッグヤード（大滝）

表 1 人.Lの滝

\begin{tabular}{|c|c|c|c|c|c|c|}
\hline 人工の滗所在地 & 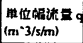 & 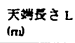 & 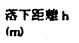 & \multicolumn{2}{|c|}{ 现实表栺 } & 于溯表情 \\
\hline \multirow{2}{*}{ 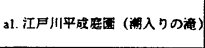 } & \multirow[b]{2}{*}{0.004} & \multirow[b]{2}{*}{0.50} & \multirow{2}{*}{0.50} & I & 状 & 错状 \\
\hline & & & & $\pi$ & 布状 & \&らけ \\
\hline \multirow{2}{*}{ 22. 京王ブラザホテル（南訨入口） } & \multirow[b]{2}{*}{0.006} & \multirow[b]{2}{*}{0.07} & \multirow[b]{2}{*}{0.30} & I & 基状 & 唒状 \\
\hline & & & & $\Pi$ & 布状 & 布状 \\
\hline \multirow{2}{*}{$\begin{array}{l}\text { 23. シェラトン・トラキョウベ1 } \\
\text { (ロピーのカスケード) }\end{array}$} & \multirow{2}{*}{$\begin{array}{l}0.004 \\
0.004\end{array}$} & \multirow{2}{*}{$\begin{array}{l}0.30 \\
0.30\end{array}$} & \multirow{2}{*}{$\begin{array}{l}0.30 \\
0.35\end{array}$} & I & 笑状 & 状 \\
\hline & & & & L & 布状 & 布状 \\
\hline \multirow{2}{*}{ 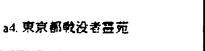 } & \multirow[b]{2}{*}{0.004} & \multirow[b]{2}{*}{0.09} & \multirow[b]{2}{*}{1.20} & I & 楚状 & 䧊状 \\
\hline & & & & 미 & ばらけ & ばらけ \\
\hline \multirow{2}{*}{ a5.東宗ドーム } & \multirow[b]{2}{*}{0.008} & \multirow{2}{*}{0.80} & \multirow[b]{2}{*}{0.20} & I & 腾状 & 踔状 \\
\hline & & & & 미 & 布状 & 布状 \\
\hline \multirow{2}{*}{ 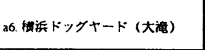 } & \multirow[b]{2}{*}{0.010} & \multirow[b]{2}{*}{1.17} & \multirow[b]{2}{*}{10.00} & $\mathrm{I}$ & 関状 & 白乐状 \\
\hline & & & & II & ぼらけ & ばらけ \\
\hline \multirow{2}{*}{ 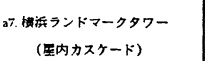 } & \multirow{2}{*}{0.004} & \multirow{2}{*}{0.30} & \multirow{2}{*}{0.45} & I & 䙲状 & 新状 \\
\hline & & & & ㅁ] & 布状 & ばらけ \\
\hline
\end{tabular}

ズレの比較は是非とも欲しいデータである。そこで 現実の表情との検証を行った。その目的は以下の 2 点である。

i ）予測図の現実の表情への適用性の検証

ii ）経験式の採用における仮定の不備や 2 次的な 要因を無視していることによるモデルと現実 の差の検証

落水過程 四に関しては、前述の筆者らの論文やそ の他の既存研究が多くあるので、今回は落水過程 I、I I対象とした。

検証対象は、横浜ドッグヤード（大滝）（写真 4 ) 他、首都圈の人工の滝 7 ヶ所と大河内秒防堰堤 （写真 5 ）他、安倍川砂防堰堤 10 ケ所である。人 工の滝は、河川横断構造物に比べて構造物のスケー ルや流量が絶対的に小さいが、モデルに近い理想的 な状況が設定されている。また砂防工においては構 造物の粗度や接近流速などの問題があるが、スケー ルや流量は充分なものを持っている。

これらのデー夕を落水表情予測図にプロットし、 予測上の表情と現実の表情の比較を行った。

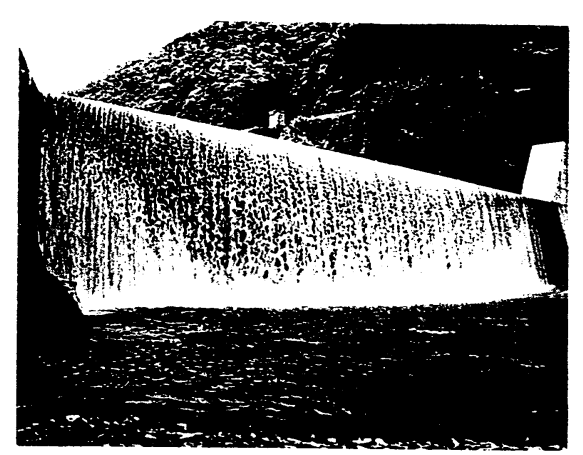

写真 5 大河内砂防ダム

表 2 砂防工

\begin{tabular}{|c|c|c|c|c|c|c|c|c|}
\hline \multicolumn{3}{|c|}{ 的的夕么所在地 } & 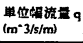 & $\begin{array}{l}\text { 天端辰さ L } \\
\text { (m) }\end{array}$ & 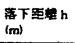 & \multicolumn{2}{|c|}{ 非电貫得 } & 于列票得 \\
\hline \multirow{2}{*}{\multicolumn{3}{|c|}{ b1. 大问内政眆夕ム主夕ム }} & \multirow{2}{*}{0.069} & \multirow{2}{*}{3.0} & \multirow{2}{*}{11.5} & I & 白来状 & 梛入り \\
\hline & & & & & & II & Ifbit & Ifolt \\
\hline \multirow{2}{*}{ b2. } & \multirow{2}{*}{ ' } & \multirow{2}{*}{ 泺 1 吅夕ム } & \multirow{2}{*}{0.063} & \multirow[b]{2}{*}{2.0} & \multirow[b]{2}{*}{7.3} & I & 白糸状 & 两入ク \\
\hline & & & & & & II & ばらH & ばらけ \\
\hline \multirow{2}{*}{ b3. } & \multirow{2}{*}{ ' } & \multirow{2}{*}{ 实 2 骶 } & \multirow{2}{*}{0.058} & \multirow[b]{2}{*}{2.0} & \multirow[b]{2}{*}{3.3} & I & 白系杜 & 两入り \\
\hline & & & & & & II & \&5H & Bfist \\
\hline \multirow{2}{*}{\multicolumn{2}{|c|}{ 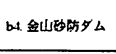 }} & \multirow{2}{*}{ 主多么 } & \multirow{2}{*}{0.199} & \multirow{2}{*}{3.0} & \multirow[b]{2}{*}{12.5} & $\mathrm{I}$ & 白系犹 & 軳入り \\
\hline & & & & & & II & ISSH & ISbH \\
\hline \multirow{2}{*}{ b5. } & \multirow{2}{*}{ ' } & \multirow{2}{*}{ 实1副多么 } & \multirow{2}{*}{0.152} & \multirow[b]{2}{*}{2.3} & \multirow[b]{2}{*}{4.9} & I & 白系状 & 政状 \\
\hline & & & & & & II & last & lisht \\
\hline \multirow{2}{*}{66 . } & \multirow{2}{*}{ ' } & \multirow{2}{*}{ 第2 捚タム } & \multirow{2}{*}{0.122} & \multirow{2}{*}{2.0} & & I & 白系状 & 西入 \\
\hline & & & & & 3.8 & II & lasit & ビらけ \\
\hline$b \bar{x}, 3$ & 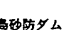 & 表么 & & & & I & 白系状 & 白米状 \\
\hline & & & 0.080 & 7.8 & 8.0 & II & HEH & H5t \\
\hline & & 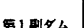 & & & & I & 白糸状 & 而入 \\
\hline & 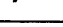 & 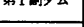 & 0.082 & 2.0 & 8.6 & II & Ifsit & HEH \\
\hline b9. & , & 慗 2 到 & 0.083 & 20 & 49 & $\mathrm{I}$ & 白系状 & 雨入 \\
\hline & & & 0.005 & 2.0 & 4.9 & II & 活けH & ばらけ \\
\hline & , & 第3 到 & 0.088 & & & I & 自系状 & 两入 $\eta$ \\
\hline & & & & 2.0 & 5.6 & II & ばらけ & BSWH \\
\hline
\end{tabular}

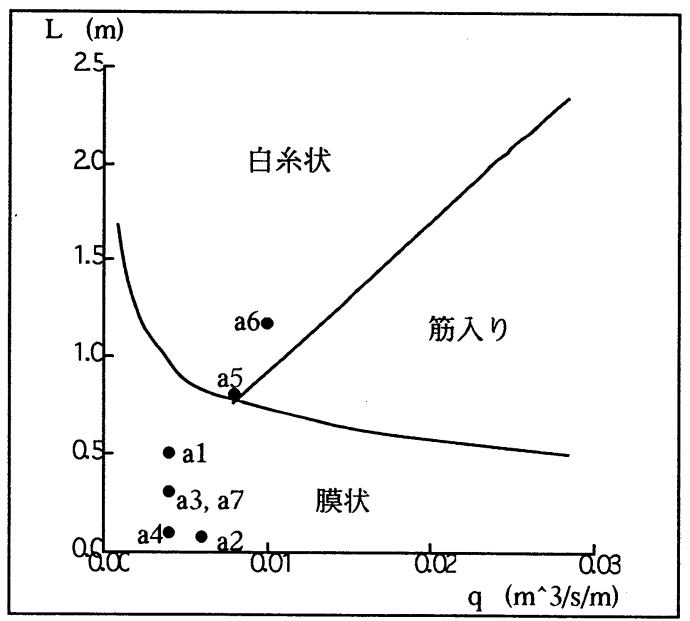

図 7 人工の滝検証結果（落水過程 I )

(2) 検証結果とその考察

データ（流量、天端長さ、落下距離）と観察され た表情及び予測された表情をそれぞれ表にまとめた ものが表 1、表 2 である。 


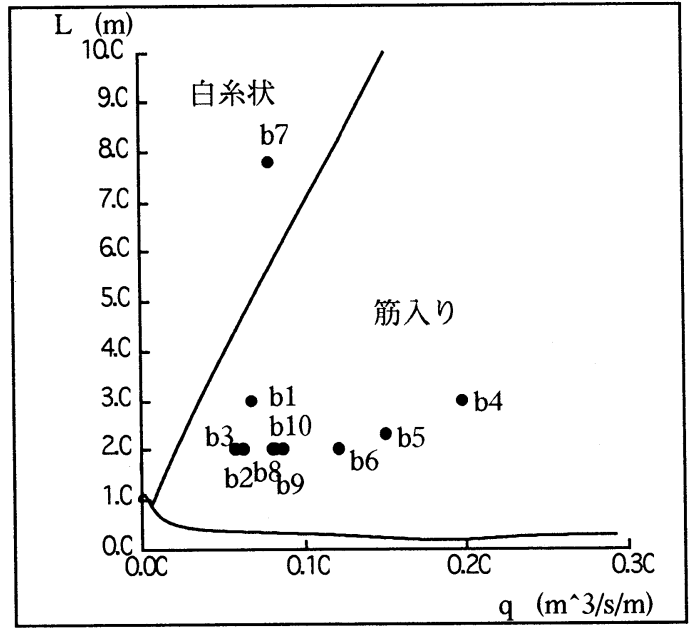

図 8 砂防工検証結果 (落水過程 I)

\section{i ）落水過程 I}

人工の滝（図 7 参照）においては、横浜ドッグ ヤード（a 6) 以外、全て予測と現実が一致してい た。しかし横浜ドッグヤードでは、水理学上は乱流 境界層が発達し、白系状の必要条件を満たしている にも拘わらず十分な空気混入が起こっていない。こ れは、白釆状の水理学的条件 (乱流境界層が水脈表 側の自由表面に達する) が必要条件でしか無く、空 気混入が生じる十分条件ではないことが現実の表情 の中に現れたものと見ることができる。この問題に 関しては、今後より詳細な研究が必要であろう。し かしa6の相違は残るものの 7 例全体として図 7 を見 ると、本論で示した膜状の領域はその十分条件とし て活用できると考える。

一方、砂防工（図８参照）においては、棌佐島主 ダム（b6）以外、すべて現実と予測は異なってい た。今回のモデルでは、落ち口の形状や構造物表面 の粗度を考慮せず、十分な堰上げによって接近流速 を0と仮定している。それらの影響が出ていると考 えられるが、落ち口に凹凸が激しくついているとそ こで剥離が起こり空気混入が生じる、同様に構造物 表面の粗度が高いと水脈の乱れが堌加し、また十分 な堰上げがないと堰上流側の乱れがそのまま落水に 伝わってしまう。つまりこれらは全て現実の表情を 予測表情より白糸状の方向に移行させている。これ らの影響に関しては、検証においてそれらのパラ メーターを詳しく計測し、既存の水理学の知見と合 わせて考察することで、予測図の修正を行うことが 可能であると思われる。

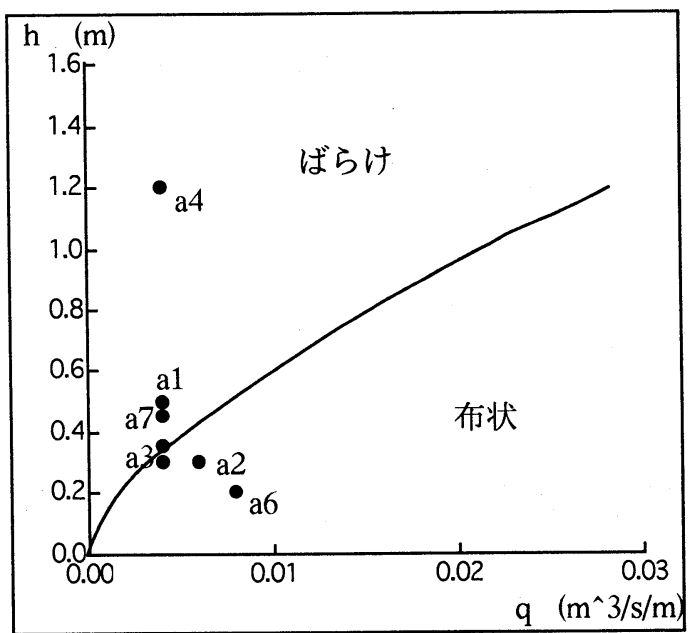

図 9 人工の滝検証結果（落水過程 II)

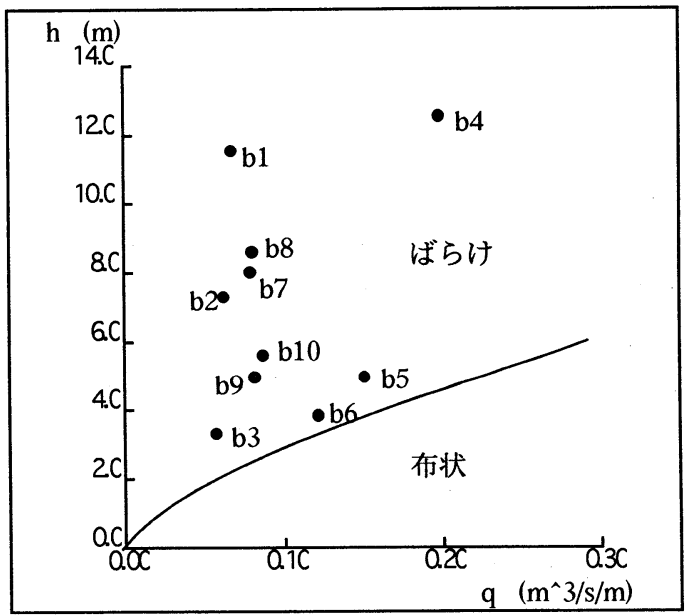

図 10 砂防工検証結果（落水過程 II）

ii）落水過程 II

人工の滝（図 9 参照）では、8 例中 5 例が現実と 予測が一致し、それ以外は異なっていた。しかし、 ばらけが生じてもすぐ着水してしまえば、ばらけが 現実には観察されないことを考慮すると大きく異 なっているのは2例（a1,a7）となる。今回ばらけ の現象に対して採用した水理モデルは、水束の不安 定条件であり、非粘性という仮定がなされていた。 人工の滝では、過程 Iでの乱れが非常に小さいた め、粘性が強く、水膜としての特性も強く保持して いる。この 2 例は、それらの仮定の不備が出たもの であると考えられる。

一方砂防工（図 10 参照）においてはばらけの データしか採集できなかったが、採集したデー夕内 ではすべて予測と現実が一致していた。今後、布状 


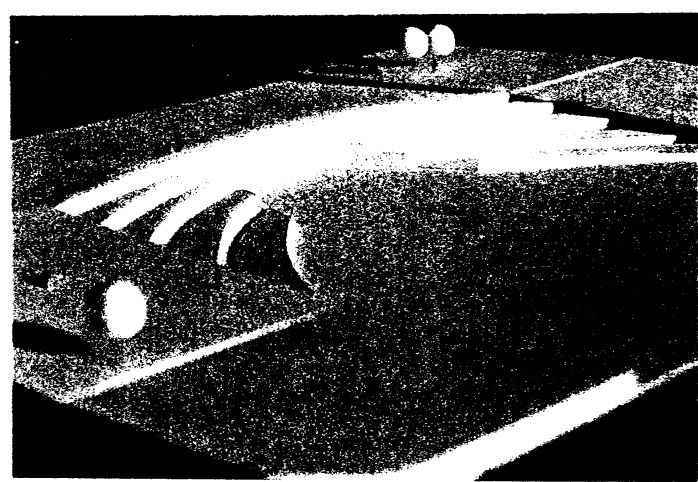

写真 6 スタディー案模型写真

のデータも採集し、より正確な検証が必要であろ う。しかし、今回の検証内では以下のことが考えら れる。砂防工の過程 I の表情は白糸状であり、乱れ が大きい。つまり人工の滝とは逆に既に落水過程 II においては粘性が少なく、水膜としての特性も希薄 である。そのため砂防工では予測の罗当性が高かっ たと考えられる。しかし、モデルに適合するような 状況が設定されれば、過程Iにおいて乱れが少なく なるはずである。その場合はこの過程の表情が布状 になり、予測と異なるものが出てくる可能性があ る。今後過程 Iの乱れとの相関について、実験等で 検証しなければならない。

4.ケーススタディー

一予測手法のデザインでの用い方

本論で示したデザイン方法論の現実への展開の可 能性を示すため、表情予測図を用いて落水表情演出 を主目的とした河川横断構造物の試設計をケースス タディーとして行った。

基礎データとして、長野県太田切川の河川条件を 用いた。諸元は以下の通りである。

. 平均川幅 $100 \mathrm{~m}$

平常時平均流量 約 $4 \sim 18 \mathrm{~m}^{3} / \mathrm{m} / \mathrm{s}$

デザインコンセプトは、落水表情の多様性、流量 変化による表情の演出である。また、レクリエー ションにも利用できることも考慮した。

それらを考慮して試設計した構造物は写真 6 の通 りである。これは、落差 $1 \mathrm{~m}$ の 5 段の多段式で、中 央部のみ 1 段 $5 \mathrm{~m}$ で落としている。また天端長さ は、湾曲型に変化させ、岸に近づくほど、下段に行

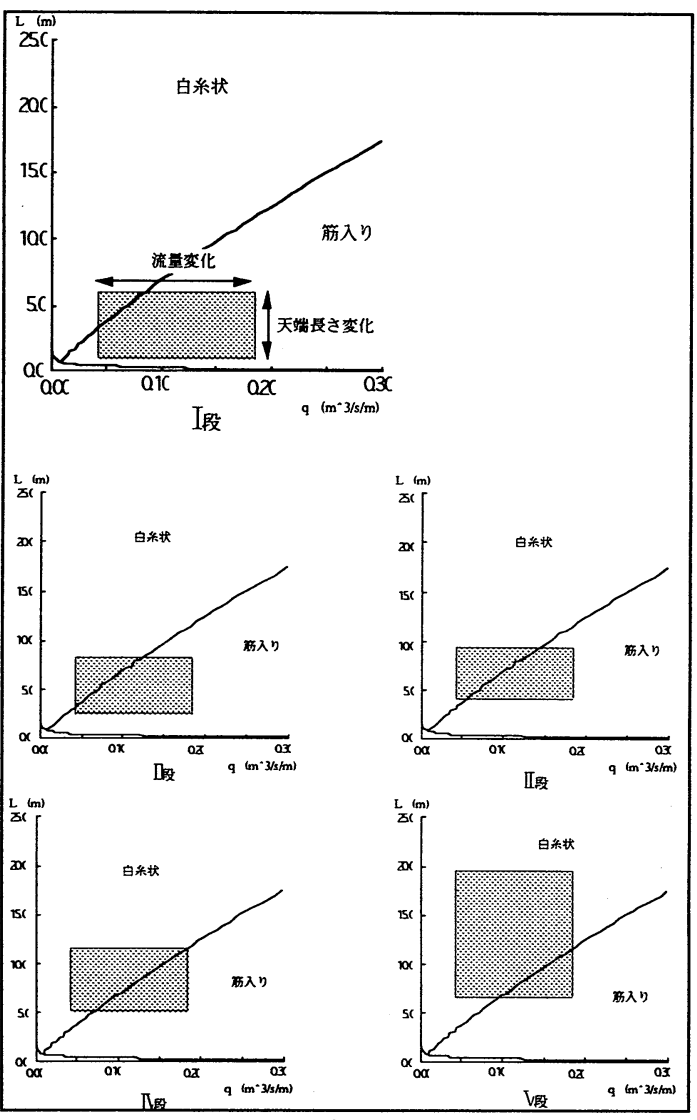

図 11 スタディー案表情予測図

くほど長くなっている。

この構造物の落水過程 I に関する落水表情予測を 図 11 に示す。それぞれの表情予測図内の四角の領 域は、縦辺が各段における水平方向の天端長さ変化 を、横辺が流量変化を示している。それぞれの段毎 に、その領域内で表情が変化し、また下段に行くに 従って白糸状の領域が増え、水の白みが増している ことが分かる。イメージスケッチを図 12 に示す。 このように本論で示した表情予測図を用いること で、恣意性を離れた水理学的な根拠に基づくデザイ ンが可能であることを示した。

\section{5. 結論}

\section{(1) 研究成果}

i ) 本論は、自由落下型の落水に対して、水理学的 知見に裏付けられた予測を中心とするデザイン 方法論を提示した。河川構造物のデザインに対 


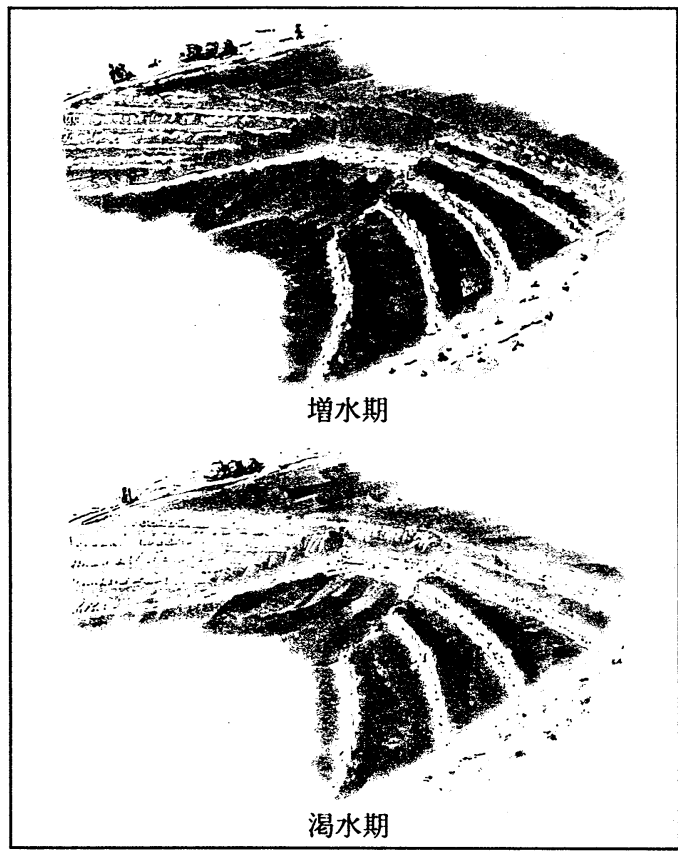

図 12 イメージスケッチ

してこのようなアプローチで研究が行われたこ とはない。本論の最も重要な意義はこの点にあ ると考える。

次に研究成果を個別に述べる。

ii）水脈の表面と裏面の相関、水の白み具合、落水 の安定度、跳水の形態に着目して、自由落下型 の落水表情を落水発生部で 3 種類、落水部で 2 種類、跳水の形で 2 種類、その結合として計 1 2 種類に分類した。

iii）水理学経験式を適用することで、規定要因と落 水表情との対応関係を明らかにし、操作可能な 4 つのデザインパラメーター（単位幅量、天端. 長さ、落差高さ、下流設定水深）を用いて、落 水表情予測図を作成した。

iv）人工の滝と砂防工を対象として現実の落水表情 によって、本論で提示した落水表情予測図を比 較し、その精度及び問題点と今後の研究課題を 明らかとした。

v ）長野県太田切川流路工の諸元を基礎データとし て利用し、落水表情予測図を用いたデザインク 法論の現実への展開の仕方を例示した。

\section{（2）今後の課題}

i ) 水理学研究者との共同研究は重要である。それ によって本研究では考慮できなかった 2 次要因 （構造物表面の粗度、落ち口の形状、接近流速 等)についても考察を行い予測の精度を高める 必要がある。

ii）現地でのより詳細な観測、計測を行い、その検 証を通して予測の精度を高める。

iii）本論で用いた予測モデルの仮定に合うような実 物大の水理実験を行い、予測の精度を高める。

iv）光の当たり具合の影響や落水を見る視点場の位 置、距離などを考慮した落水表情のより詳細な 分類を行い、現実の河川景観設計への有効性を 深める。

\section{6. 謝辞}

本論作成にあたっては、多くの人の助力を得た。 東京大学河原能行助教授には、水理学経験式の適用 に関して多くの相談に乗っていただいた。日建設計 小野氏には人工の滝について、安倍川工事事務所の 水谷氏には砂防工について、天竜川工事事務所の白 江氏にはスタディー基礎データについて、それぞれ のデー夕収集に対して多くの協力を頂いた。また宇 都宮で行われた土木計画学研究発表会では、宇都宮 大須賀克三教授にコメントしていただき、多くの有 益な助言を得ることができた。最後ではあるが協力 いただいた皆様に感謝の意を述べさせていただきた w。

\section{参考文献}

1）一丸義和,候原修: 落水表情に着目した河川横断構造 物のデザイン方法論一越流型固定堰の表情予測一、 土木計画学研究 ·講演集No.16 (1)、1993

2) 土木学会編 : 水理公式集、pp.291、技報堂出版、1985

3) 土木学会編 : 水理公式集、pp.174、技報堂出版、1963

4) 本間仁,安芸盿一: 物部水理学、pp.461、岩波書店、 1962

5 ）柴田道生：実用水工学とその計算例、pp.83-85、 現代理工学出版、1973

6）土木学会編：水理公式集、pp.317、技報堂出版、1985

7）日本流体力学会編：流体力学ハンドブック、pp.725、 丸善、 1987

8）一丸義和：河川横断構造物におけるデザイン方法論 東京大学卒業論文、1993 
水理学的知見に基づく自由落下型落水形態の表情予測とデザイン方法論

\section{星野 裕司、篠原 修}

魅力ある落水表情は河川景観において重要な役割を担っている。しかし河川横断構造物では設計から それが考慮されることは稀であり、人工の滝のデザインでも経験に基づくのみで水理学的な考察が欠 如している。そこで本論は、自由落下型の落水を対象として、現実表情の観察による落水表情の分 類、既存の水理学経験式等の適用による規定要因の考察、予湘と現実表情との此較を通して、落水表 情の予測、制御が可能となるデザイン方法論を提示した。以上のように本論は、水理学上の新たな知 見を得るものではないが、落水現象を景観的視点から全体的に把握し、水理学上の理論をデザイン方 法論へ統合したことに意義があると考えている。

An Estimation of the Texture of Free Falling Water Based on Hydraulic Theories and its Application to a Water Design Method

$$
\text { Yuji HOSHINO, Osamu SHINOHARA }
$$

The attractive texture of falling water adds a special feature to the riverscape. But it is seldom that the texture is considered in designing a river structure. Even an artificial waterfall is designed based on the experience of a designer without objective consideration. In this paper, focusing on free falling water, the authors tried to classify the texture by observing in the field, determine the primary factors of the texture by applying the hydraulic formulas, and compare the texture of the existing falling waters to the estimated ones. the authors proposed the method of estimation and design for falling water. 